\title{
Characteristics of Dried Cocoa Beans (Theobroma cacao L.) Color Using Response Surface Methodology
}

\author{
DOI: $10.18196 /$ pt.2019.097.82-92
}

\author{
Sri Hartuti ${ }^{1 *}$, Nursigit Bintoro ${ }^{2}$, Joko Nugroho Wahyu Karyadi ${ }^{2}$, Yudi Pranoto ${ }^{3}$ \\ ${ }^{1}$ Department of Agricultural Engineering, Universitas Syiah Kuala. \\ Jl. Tgk. Hasan Krueng Kalee, No. 3 Kopelma Darussalam-Banda Aceh 23111, Indonesia. \\ ${ }^{2}$ Department of Agricultural and Biosystem Engineering, Universitas Gadjah Mada. \\ Jl. Flora No. 1, Bulaksumur, Yogyakarta 55281, Indonesia \\ ${ }^{3}$ Department of Food and Agricultural Product Technology, Universitas Gadjah Mada. \\ Jl. Flora No. 1, Bulaksumur, Yogyakarta 55281, Indonesia \\ ${ }^{*}$ Corresponding author, email: sri.hartuti@gmail.com
}

\begin{abstract}
The research aimed to study the effects of storage time of cacao fruit before fermentation, aeration rate and temperature of fermenter during fermentation on the color value of dry cocoa beans, including the value of $L$ *, a ${ }^{*}, b^{*}$, chroma, hue, and RGB, and their relationship using response surface methodology.. The results showed that storage time of cacao fruits before fermentation, aeration rate and temperature of the fermenter had an influence on the color values of $L *, a *$ * $b^{*}$, chroma, hue, and RGB of dried cocoa beans produced. The highest brightness prediction value of chroma color was \pm 26 obtained in the treatment of the storage time of 9-day, aeration rate of 0.4 liters/minute, and fermenter temperature of $50^{\circ} \mathrm{C}$ Meanwhile, the highest hue prediction value was 51.8 obtained in the treatment of storage time of 9 days, aeration rate of 0.3 liters / minute, and fermenter temperature of $50^{\circ} \mathrm{C}$. Furthermore, the RGB color of dried cocoa beans showed that the color range of $R$ (red) and G (green) of cocoa beans after fermentation was higher when compared to cocoa beans without fermentation, while the value of color $B$ (blue) had a different tendency showing that dried fermented cocoa beans had a lower blue range compared to unfermented cocoa beans.
\end{abstract}

Keywords: Chroma, hue, RGB, cocoa beans, fermentation

\section{ABSTRAK}

Penelitian ini bertujuan untuk mempelajari pengaruh dan hubungan waktu pemeraman buah kakao sebelum fermentasi, laju aerasi dan suhu fermenter selama fermentasi terhadap nilai warna keping biji kakao kering menggunakan response surface methodology, meliputi warna L*, a*, b*, chroma, hue, dan RGB. Hasil penelitian menunjukkan bahwa pemeraman buah kakao sebelum fermentasi, laju aerasi dan suhu fermenter memiliki pengaruh terhadap nilai warna $L^{*}, a^{*}, b^{*}$, chroma, hue, dan RGB keping biji kakao kering yang dihasilkan. Nilai prediksi kecerahan tertinggi warna chroma yaitu \pm 26 yang diperoleh pada waktu pemeraman buah kakao 9 hari, laju aerasi 0,4 liter/menit, dan suhu fermenter sebesar 50 C. Sedangkan prediksi nilai warna hue tertinggi diperoleh sebesar 51,8 pada waktu pemeraman buah kakao 9 hari, laju aerasi 0,3 liter/menit, dan suhu fermenter 50 C. Selanjutnya warna RGB biji kakao kering menunjukkan bahwa rentang warna R (red) dan G (green) biji kakao setelah fermentasi lebih tinggi jika dibandingkan dengan biji kakao tanpa fermentasi, sedangkan nilai warna B (b/ue) mempunyai kecenderungan yang berbeda, yaitu biji kakao kering fermentasi memiliki rentang warna biru yang lebih rendah dibandingkan pada biji kakao yang tidak difermentasi.

Kata Kunci: Chroma, Hue, RGB, Biji kakao, Fermentasi

\section{INTRODUCTION}

The postharvest process of cocoa beans is a de- an unfavorable flavor compared to Ghana and terminant of flavor formation in dried cocoa beans Ivory Coast cocoa beans. Indonesian cocoa beans (Krähmer et al., 2015). Postharvest handling of are only used as fillers for cocoa products, while cocoa beans is important, in order to obtain high- the typical cocoa flavor and taste of the products quality coca beans favored by consumers (Kongor et al., 2016). Generally, consumers of cocoa beans are producers of processed cocoa products in which cocoa beans are used as raw materials for food and beverage products. Therefore, improving food quality and safety must be continuously improved. So far, Indonesian cocoa beans are considered to have are obtained from other countries' cocoa beans (Munarso 2016). Thus, the postharvest handling of cocoa beans which consists of ripening, fermentation, drying and storing of cocoa beans must be continually improved to improve the quality of the cocoa beans produced.

Ripening of cacao fruits or storing cocoa fruit 
before the fermentation process aims to homogenize the maturity of the cocoa fruit, and is considered to have a good influence on the fermentation process (Puslitbang Perkebunan, 2010). Even the storage time of cocoa fruit and fermentation time can also affect the quality and appearance of fermented cocoa beans (Afoakwa et al., 2012; Afoakwa, 2016). Furthermore, the fermentation of cocoa beans aims to form a distinctive flavor of chocolate (Sulaiman and Yang 2015), produce hollow and brown seed pieces, reduce the bitter taste and the laces found in cocoa beans (Afoakwa et al., 2012), and produce seeds with good quality and aroma (Menezes et al., 2016). Indicators of well-fermented and dried cocoa beans are brown colored, low in taste and bitter, and lack of sour taste and smoky taste (Afoakwa et al., 2012).

Color is one of the visual parameters that is a concern for grain products and plantation products (Dinar, Suyantohadi, and Falah 2012), with the aim of providing information on the quality of a product (Indarto and Murinto 2017; Mardhotillah, Atfianto, and Rahmadhani 2018). The characteristics and changes in purple color on the pieces of cocoa beans before fermentation, which turn brown after fermentation and dried, are one of the indicators that are very important in determining the quality of cocoa beans. Visual color evaluation of cocoa beans is strongly influenced by various other factors and has a very wide range of ratings. Therefore, the measurement of the color value of cocoa bean pieces using color meters is important to distinguish the colors from each sample expressed with numerical values.

Measuring the color of cocoa beans can be done to find out the color range obtained in dried cocoa beans in more detail than direct observation. The model often used in color measurement is one of the colors of $\mathrm{L}^{*} \mathrm{a}{ }^{*} \mathrm{~b}$ * which is the international standard for color measurement adopted by the Commission Internationale de I'Eclairage (CIE) in 1976 (Mendoza, Dejmek, and Aguilera 2007). One method of analysis that can be used is response surface methodology (RSM). Analysis using RSM for color measurement on several foodstuffs with the same method has been carried out, including: to know the effect of substitute flour and particle size on the color of wheat bread (Marcin et al. 2016) and to know the effect of changes in the time and temperature of frying chips papaya (Wexler et al. 2016). Therefore, research to study the color characteristics of dried cocoa beans needs to be carried out.

The purpose of this study was to study the effects of cacao fruit storage time before fermentation, aeration control and fermenter temperature during fermentation on the color of dried cocoa beans produced and their relationship using response surface methodology.

\section{MATERIALS AND METHODS}

Sample Preparation

The cocoa fruit used in this study was obtained from an orchard in Tanen, Hargobinangun Village, Pakem District, Sleman Regency, Yogyakarta, Indonesia. Cocoa samples were chosen with uniform type and maturity, which was marked by yellow fruit skin. The cocoa fruits then were placed in a clean room with ambient air temperature for 1, 5 and 9 days. Then the cocoa fruits were split and the cocoa beans were separated from the skin and placenta then fermented for 5 days.

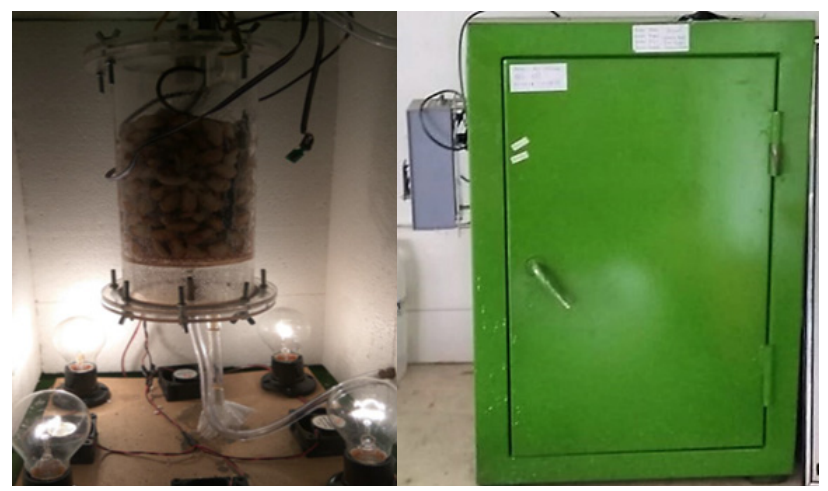

Figure 1. Fermented cocoa beans using a controlled reactor 


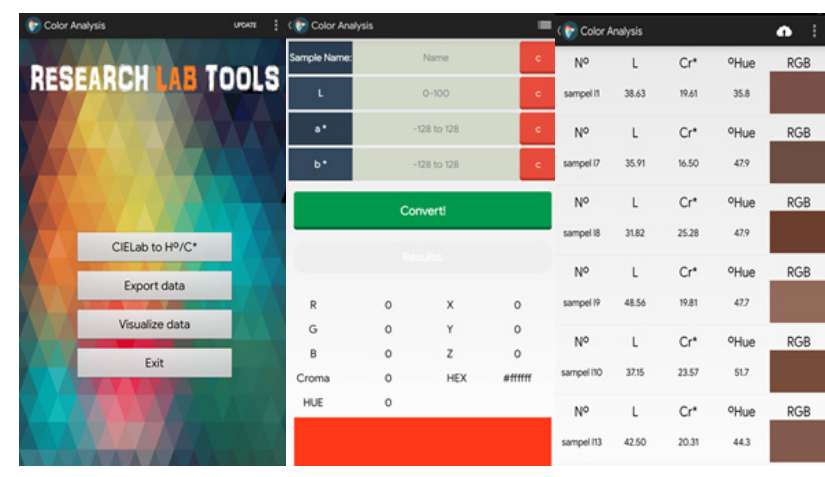

Figure 2. Description of the color analysis software used to visualize the color values of $L, a^{\star}, b^{\star}$ of dried cocoa beans from the measurement results

Fermentation of $\pm 1 \mathrm{~kg}$ of cocoa beans was carried out using a reactor tube as shown in Figure 1 in each treatment. The reactor tube was placed in a fermenter room equipped with an aeration rate control system and fermenter room air temperature. Control of fermenter air temperature and aeration rate started on the second day until the fifth day of fermentation. Next, fermented cocoa beans were dried using a cabinet dryer with a temperature of $50{ }^{\circ} \mathrm{C}$ for $22-24$ hours. Then the measurement of the color of the dried cocoa beans was done using a TES 135 color meter.

\section{Experimental design}

This research was conducted with response surface methodology (RSM) design with 3 experimental factors, namely the storage time of cocoa fruit before fermentation consisting of $1,5,9$ days, aeration rate consisting of $0.2,0.3,0.4 \mathrm{~L} /$ minute and fermenter air temperature consisting of 40, 50, 60 ${ }^{\circ} \mathrm{C}$. The split test then was carried out on fermented dried cocoa beans to see the color change of the cocoa beans. The color value of each sample was measured by the color meter TES 135 . Measurements are based on the $L^{*} a^{*} b^{*}$ color system. The color values of $L^{*}, a^{*}$, and $b^{*}$ of the sample were calculated as $\mathrm{L}^{*}$ (Ls-LO), where the value of 100 is perfect/brightest (white) and 0 is the darkest color (black). Parameters a* (as-a0) are green-red ranges, where: green in the range of negative values and red or reddish colors have values in the positive range. Parameters $b^{*}(b s-b 0)$ are blue-yellow ranges, where blue is in the range of negative values and the value of $b^{*}$ positive shows yellow (Mendoza et al., 2007; Afoakwa. 2012; Marcin et al., 2016). Based on the color values of $\mathrm{L}^{*}, \mathrm{a}^{*}$, and $\mathrm{b}^{*}$ that have been obtained, then the chroma and hue color values were calculated according to Equations 1 and 2 (Wexler et al., 2016; Afoakwa, 2016). In addition, the color visualization of RGB (red green blue) results of measurement of dried cocoa beans was done by inputting the average value of $\mathrm{L}^{*}, \mathrm{a}^{*}, \mathrm{~b}^{*}$ as measured in the color analysis (RESEARCH LAB TOOLS) software as shown in Figure 2.

$C^{*}=\sqrt{\left.\left(a^{* 2}\right)+b^{* 2}\right)}$
$h=\operatorname{arcig}\left(b^{*} / a^{*}\right)$ atau $h=\tan ^{-1}\left(b^{*} / a^{*}\right)$

Remarks: $\mathrm{C}^{*}$ is the chroma coordinate, indicating brightness in which the highest value indicates the brightest value. $\mathrm{H}$ is the value of the hue angle in which at a low value indicating a more reddish value and a higher value indicates a more yellowish color.

\section{Statistical analysis}

$L^{*}, a^{*}, b^{*}$ color measurements were carried out in three replications, then the average value of the measurement results were used for chroma and hue color calculations, RGB calculation and RGB color visualization. Furthermore, data analysis was carried out using response surface methodology (RSM), with the help of Minitab 14 software to determine the relationship and influence of storage time of cocoa fruit, aeration rate and temperature of the fermenter on chroma and hue color values in dried cocoa beans which consisted of 20 treatments as shown in Table 1 . The results of data analysis using RSM will produce a mathematical equation with a second-order polynomial model 
whose function is quadratic (Hartuti \& Supardan, 2013; Bitaraf et al. 2012; Khuri 2017) as follows:

$\mathrm{Y}=\beta_{0}+\beta_{1} \mathrm{X}_{1}+\beta_{2} \mathrm{X}_{2}+\beta_{3} \mathrm{X}_{3}+\beta_{11} \mathrm{X}_{1}^{2}+\beta_{22} \mathrm{X}_{2}^{2}+\beta_{33} \mathrm{X}_{3}^{2}$ $+\beta_{12} X_{1} X_{2}+\beta_{13} X_{1} X_{3}+\beta_{23} X_{2} X_{3}$

Remarks: $\mathrm{Y}$ is the response value of the chroma and hue color values in the fermented cocoa beans using a controlled reactor. $\beta_{0}$ is intercept/constant, $\beta_{1}, \beta_{2}, \beta_{3}$ is a linear coefficient, $\beta_{11}, \beta_{22}, \beta_{33}$, is a quadratic coefficient, $\beta_{12}, \beta_{13}, \beta_{23}$ is the interaction coefficient between treatments. X1 is the storage time of cocoa fruits before fermentation (days), X2 is the air aeration rate factor (liters/minute), $\mathrm{X} 3$ is the fermenter air temperature $\left({ }^{\circ} \mathrm{C}\right)$.

\section{RESULTS AND DISCUSSION}

The results showed that the treatment of storage time of cacao fruits before fermentation, aeration rate and temperature of the fermenter air had an influence on the color change of the dried cocoa beans produced. The calculation results of the average color values of $\mathrm{L}^{*}, \mathrm{a}^{*}, \mathrm{~b}^{*}$, chroma, and hue, as well as RGB color visualization are shown in Table 1, while the color of the fermented dried cocoa beans is shown in Table 2 . The fermentation process is one of the processes done to get the color change of cocoa beans from purple to brown with the characteristics of hollow seed pieces. Even the color characteristics of dried cocoa beans are one way to identify the quality of dried cocoa beans.

The average brightness index or L* (lightness) for all treatments of fermented cocoa beans was

Table 1. Color of $L^{\star}, a^{\star}, b^{\star}$, chroma, hue, RGB and RGB color illustration of fermented dried cocoa beans

\begin{tabular}{|c|c|c|c|c|c|c|c|c|c|c|c|}
\hline \multicolumn{3}{|c|}{ Treatment } & \multicolumn{3}{|c|}{$\begin{array}{l}\text { Average color of dried cocoa } \\
\text { beans (measurement) }\end{array}$} & \multicolumn{2}{|c|}{$\begin{array}{l}\text { Average color of dried } \\
\text { cocoa beans (theoretical) }\end{array}$} & \multicolumn{3}{|c|}{ RGB } & \multirow[t]{2}{*}{$\begin{array}{l}\text { RGB illustration o } \\
\text { calculation results }\end{array}$} \\
\hline $\mathrm{X} 1$ & $\mathrm{X} 2$ & $\mathrm{X} 3$ & $L^{*}$ & $a^{*}$ & $b^{*}$ & Chroma (c) & Hue $(\mathrm{H})$ & $\mathrm{R}$ & G & B & \\
\hline 1 & 0,2 & 40 & 38.63 & 15.91 & 11.47 & 19.61 & 35.79 & 116 & 77 & 59 & \\
\hline 9 & 0,2 & 40 & 30.63 & 14.15 & 17.16 & 22.24 & 50.48 & 119 & 82 & 78 & \\
\hline 1 & 0,4 & 40 & 39.14 & 14.98 & 8.65 & 17.30 & 30.01 & 113 & 62 & 47 & \\
\hline 9 & 0,4 & 40 & 32.41 & 20.54 & 18.49 & 27.64 & 41.99 & 110 & 77 & 64 & \\
\hline 1 & 0,2 & 60 & 36.17 & 12.34 & 13.30 & 18.14 & 47.16 & 105 & 63 & 49 & \\
\hline 9 & 0,2 & 60 & 31.64 & 16.61 & 16.22 & 23.21 & 44.31 & 130 & 54 & 69 & \\
\hline 1 & 0,4 & 60 & 35.91 & 11.06 & 12.24 & 16.50 & 47.90 & 107 & 77 & 65 & \\
\hline 9 & 0,4 & 60 & 31.82 & 16.94 & 18.76 & 25.28 & 47.93 & 107 & 63 & 45 & \\
\hline 1 & 0,3 & 50 & 48.56 & 13.33 & 14.66 & 19.82 & 47.73 & 145 & 106 & 90 & \\
\hline 9 & 0,3 & 50 & 37.15 & 14.60 & 18.51 & 23.57 & 51.73 & 118 & 77 & 58 & \\
\hline 5 & 0,2 & 50 & 39.29 & 17.50 & 16.84 & 24.29 & 43.89 & 121 & 87 & 72 & \\
\hline 5 & 0,4 & 50 & 40.34 & 12.36 & 14.01 & 18.68 & 48.57 & 129 & 90 & 80 & \\
\hline 5 & 0,3 & 40 & 42.50 & 14.54 & 14.18 & 20.30 & 44.28 & 130 & 90 & 77 & \\
\hline 5 & 0,3 & 60 & 42.11 & 14.61 & 13.43 & 19.85 & 42.58 & 148 & 109 & 97 & \\
\hline 5 & 0,3 & 50 & 49.99 & 13.82 & 13.15 & 19.08 & 43.58 & 123 & 84 & 69 & \\
\hline 5 & 0,3 & 50 & 39.73 & 14.29 & 14.91 & 20.65 & 46.21 & 104 & 70 & 55 & \\
\hline 5 & 0,3 & 50 & 38.57 & 12.49 & 15.17 & 19.65 & 50.54 & 115 & 75 & 61 & \\
\hline 5 & 0,3 & 50 & 39.49 & 14.89 & 15.07 & 21.19 & 45.34 & 118 & 79 & 62 & \\
\hline 5 & 0,3 & 50 & 37.68 & 14.39 & 16.38 & 21.80 & 48.69 & 125 & 89 & 76 & \\
\hline 5 & 0,3 & 50 & 41.40 & 13.10 & 13.08 & 18.51 & 44.96 & 116 & 77 & 59 & \\
\hline
\end{tabular}


Table 2. Results of the calculation and visualization of the color of dried unfermented cocoa beans

\begin{tabular}{ccccccccccc}
\hline Treatment & \multicolumn{2}{c}{$\begin{array}{c}\text { Average color of dried cocoa } \\
\text { beans (measurement) }\end{array}$} & \multicolumn{2}{c}{$\begin{array}{c}\text { Average color of dried } \\
\text { cocoa beans (theoretical) }\end{array}$} & & RGB & & $\begin{array}{c}\text { RGB illustration of } \\
\text { calculation results }\end{array}$ \\
\hline Unfermented & $\mathrm{L}^{*}$ & $\mathrm{a}^{*}$ & $\mathbf{b}^{*}$ & Chroma (c) & Hue (H) & $\mathrm{R}$ & $\mathrm{G}$ & $\mathrm{B}$ & \\
\hline 1-day storage time & 38.63 & 15.91 & 11.47 & 19.61 & 35.79 & 116 & 77 & 59 & \\
5-day storage time & 30.63 & 14.15 & 17.16 & 22.24 & 50.48 & 119 & 82 & 78 & \\
9-day storage time & 39.14 & 14.98 & 8.65 & 17.30 & 30.01 & 113 & 62 & 47 & \\
\hline
\end{tabular}

38.66, while the non-fermented dried cocoa beans had a brightness index $L^{*}$ of 34.18. Colors a* and $b^{*}$ values of dried cocoa beans fermented were 14.68 and 14.78 , respectively, while the colors of $a^{*}$ and $b^{*}$ in non-fermented dried cocoa beans were 10.05 and 6.40 , consecutively. This shows that the fermented cocoa beans had a slightly higher brightness than the unfermented ones. Likewise, the colors $\mathrm{a}^{*}$ and $\mathrm{b}^{*}$ obtained in fermented coca beans were also higher. Fermented cocoa beans had a higher reddish and yellowish color than unfermented dry cocoa beans. According to Afoakwa et al. (2012) the increase in yellowish color that occurs in fermented cacao bean chips is due to the presence of oxidized polyphenols, during the fermentation process as a result of enzymatic oxidation by oxidizing polyphenols in cacao bean chips. Furthermore, Afoakwa et al. (2011) stated in general that the increase in fermentation time caused the cocoa bean pieces to become darker, but it got brighter with the longer storage time of cocoa fruits. This may be due to the destruction of anthocyanins by enzymatic hydrolysis, which is accompanied by bleaching and browning of the cocoa beans.

\section{Chroma analysis}

Chroma analysis is used to measure the brightness of the color of the seed pieces produced. The highest chroma value indicates the brightest color of the seed pieces. The results showed that the chroma of the fermented cocoa beans was higher than the color of the unfermented cocoa beans as shown in Table 1 and Table 2. Based on the results of the analysis of the chroma variants of fermented dry cocoa beans as shown in Table 3, $\mathrm{R}^{2}$ was $78,91 \%$, which means that the storage time of cocoa fruit, aeration rate and temperature of the fermenter air have an effect of $78.91 \%$ on the chroma of fermented cocoa beans. It is estimated that there are still other factors that influence the chroma discoloration of the fermented dried cocoa beans produced, among others because the conditions of the fermentation process conditions that have not been optimal in this study, are marked by differences in color and characteristics of cocoa beans in the upper, middle and lower tubes during the fermentation process. In addition, the

Table 3. Analysis of chroma variants of fermented dried cocoa beans

\begin{tabular}{lcccc}
\hline Source & DF & Seq MS & Adj MS & P \\
\hline Regression & 9 & 119.184 & 13.2427 & $0.018^{*}$ \\
Linear & 3 & 95.579 & 1.5955 & 0.690 \\
\hline$X_{1}$ & 1 & 93.452 & 2.5150 & 0.395 \\
$X_{2}$ & 1 & 0.437 & 1.2841 & 0.540 \\
$X_{3}$ & 1 & 1.689 & 1.4596 & 0.514 \\
\hline Square & 3 & 6.322 & 2.1075 & 0.594 \\
\hline$X_{1}^{2}$ & 1 & 4.334 & 2.3391 & 0.412 \\
$X_{2}^{2}$ & 1 & 0.650 & 1.3952 & 0.523 \\
$X_{3}^{2}$ & 1 & 1.339 & 1.3388 & 0.531 \\
\hline Interaction & 3 & 17.283 & 5.7611 & 0.209 \\
\hline$X_{1} X_{2}$ & 1 & 16.302 & 16.3021 & $0.047^{*}$ \\
$X_{1} X_{3}$ & 1 & 0.097 & 0.0968 & 0.865 \\
$X_{2} X_{3}$ & 1 & 0.884 & 0.8845 & 0.610 \\
\hline Residual Error & 10 & 31.859 & 3.1859 & \\
Lack-of-Fit & 5 & 23.721 & 4.7442 & 0.133 \\
Pure Error & 5 & 8.139 & 1.6277 & \\
Total & 19 & 151.043 & & \\
R-Square & $78.91 \%$ & & & \\
\hline & & & & \\
\hline & & & \\
\hline
\end{tabular}

$\left({ }^{*}=\right.$ significant $)$ 
discoloration of cocoa beans during fermentation and aeration rate. The results of the RSM analysis is also influenced by plant type factors (Sulaiman conducted also produce a mathematical model that and Yang 2015). can be used to predict the chroma color of dried

Based on the P-value, the regression model, cocoa beans as follows: linear model, quadratic model, interaction model, and each treatment factor have a less appropriate $\mathrm{Y}=10.719-1,020 \mathrm{X}_{1}-46,045 \mathrm{X}_{2}+0.743 \mathrm{X}_{3}+$ effect on the chroma color of the cocoa beans produced, except for the regression model and $0,058 \mathrm{X}_{1}^{2}+71,227 \mathrm{X}_{2}^{2}-0,007 \mathrm{X}_{3}^{2}+3,569 \mathrm{X}_{1} \mathrm{X}_{2}$ $+0.003 X_{1} X_{3}-0,332 X_{2} X_{3}$

the interaction between cacao fruit storage time
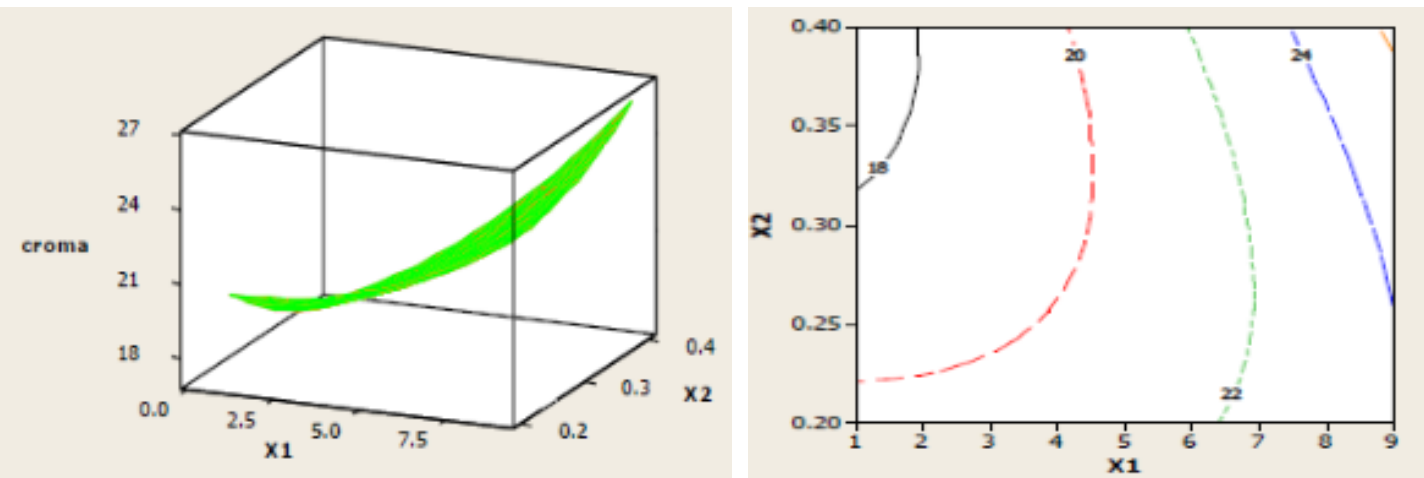

Figure 3. Plot surface and contour relationship between the chroma color of fermented cocoa beans and the storage time of cocoa fruit $\left(X_{1}\right)$ and aeration rate $\left(X_{2}\right)$ at the fermenter air temperature $\left(X_{3}\right)=50^{\circ} \mathrm{C}$
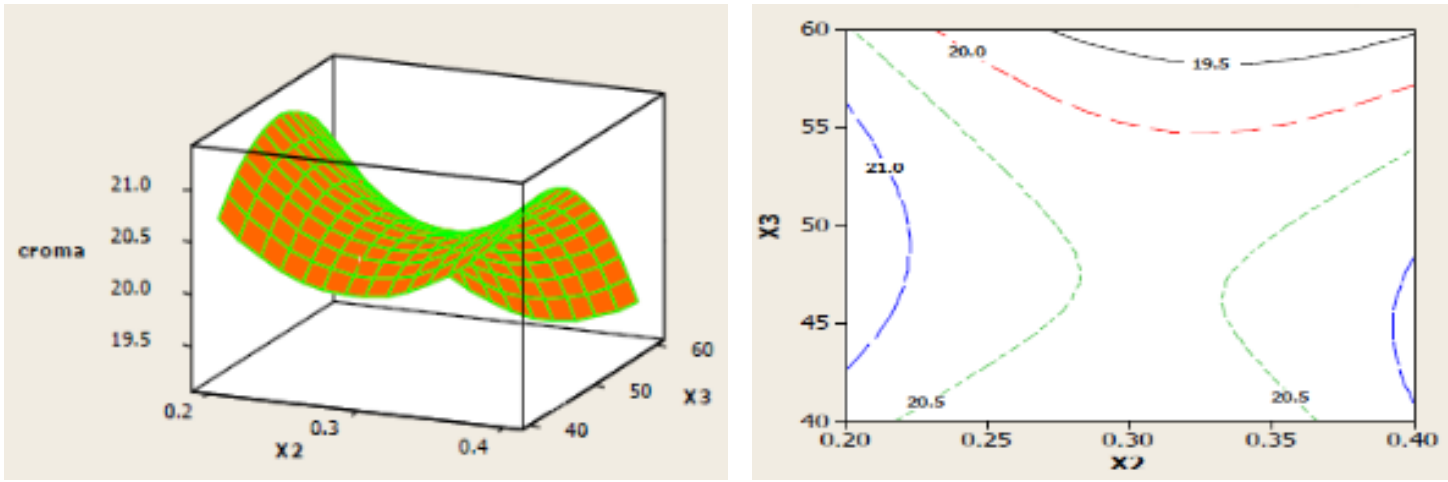

Figure 4. Plot surface and contour relationship between the chroma of fermented dried cocoa beans to an aeration rate $\left(X_{2}\right)$ and the temperature of the fermenter air $\left(X_{3}\right)$ at the time of cacao fruit ripening $\left(X_{1}\right)=5$ days
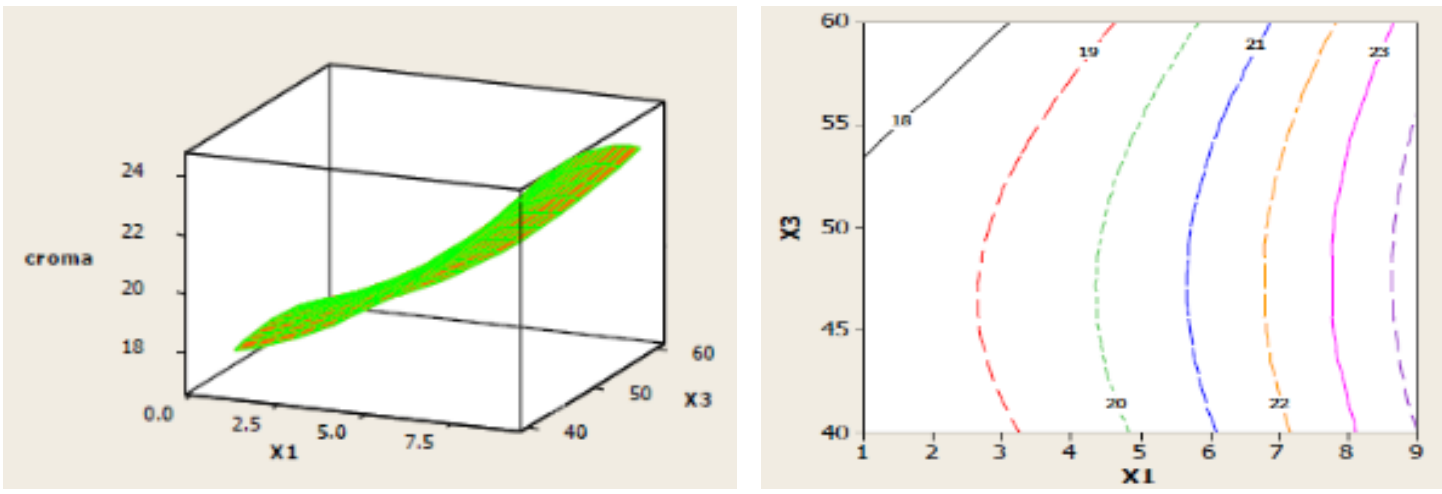

Figure 5. Plot surface and contour of the relationship between the chroma color of the fermented cocoa beans and the curing time of cocoa fruit $\left(X_{1}\right)$ and the fermenter air temperature $\left(X_{3}\right)$ at the aeration rate $\left(X_{2}\right)=0.3$ liters/minute 
Meanwhile, based on the plot surfaces and contours shown in Figure 3, Figure 4, and Figure 5, the relationship between storage time of cacao fruit, aeration rate and temperature of the fermenter and the chroma color can be seen. Figure 3 shows that when the fermenter air temperature was $50^{\circ} \mathrm{C}$, the highest chroma color was obtained at the storage time of 9 days and the aeration rate of 0.4 Liter/ minute which is equal to 26.07 . Furthermore, in Figure 4, it is known that the brightest color level is \pm 21 obtained at 5 -day storage time, fermenter air temperature of $43-55^{\circ} \mathrm{C}$, and an aeration rate of 0.2 liters/minute. Figure 5 shows that the highest chroma color acquisition is \pm 24 obtained at at the storage time of 9 days and fermentation air temperature of 40 to $55^{\circ} \mathrm{C}$, and an aeration rate of 0.3 liters/minute. Based on illustrations in Figure 3, Figure 4, and Figure 5, it can be seen that the prediction of the highest brightness level of chroma color is \pm 26 obtained at storage time of 9-day, aeration rate of 0.4 liters/minute, and air fermenter temperature of $50^{\circ} \mathrm{C}$, meaning that this treatment will get the brightest and more striking colors of cocoa from other colors. While the lowest chroma color was obtained from the treatment of 1 day storage time, aeration rate of 0.3 liters/ minute and the fermenter air temperature of $60^{\circ} \mathrm{C}$, which is equal to 17 , which means this condition will result in dimmer color intensity (weak color).

\section{Hue analysis}

Color hue analysis was carried out to determine the composition of the red and yellow colors found in dried cocoa beans. The hue expresses true colors, such as red, violet, and yellow, which are used to distinguish colors and determine redness, greenness, and so on from light (Mardhotillah et al., 2018). Based on the calculation results as shown in Table 1 and Table 2, it is known that the hue color range in fermented dried cocoa beans is $30.01-51.73$ and the color of hue in non-fermented dried cocoa beans is $25.93-42.40$.
Table 4. Analysis of hue variants of fermented dried cocoa beans

\begin{tabular}{lcccc}
\hline Source & DF & Seq MS & Adj MS & $P$ \\
\hline Regression & 9 & 119.184 & 13.2427 & $0.018^{*}$ \\
Linear & 3 & 95.579 & 1.5955 & 0.690 \\
\hline$X_{1}$ & 1 & 93.452 & 2.5150 & 0.395 \\
$X_{2}$ & 1 & 0.437 & 1.2841 & 0.540 \\
$X_{3}$ & 1 & 1.689 & 1.4596 & 0.514 \\
\hline Square & 3 & 6.322 & 2.1075 & 0.594 \\
\hline$X_{1}^{2}$ & 1 & 4.334 & 2.3391 & 0.412 \\
$X_{2}^{2}$ & 1 & 0.650 & 1.3952 & 0.523 \\
$X_{3}^{2}$ & 1 & 1.339 & 1.3388 & 0.531 \\
\hline Interaction & 3 & 17.283 & 5.7611 & 0.209 \\
\hline$X_{1} X_{2}$ & 1 & 16.302 & 16.3021 & $0.047^{*}$ \\
$X_{1} X_{3}$ & 1 & 0.097 & 0.0968 & 0.865 \\
$X_{2} X_{3}$ & 1 & 0.884 & 0.8845 & 0.610 \\
\hline Residual Error & 10 & 31.859 & 3.1859 & \\
Lack-of-Fit & 5 & 23.721 & 4.7442 & 0.133 \\
Pure Error & 5 & 8.139 & 1.6277 & \\
Total & 19 & 151.043 & & \\
R-Square & $78.91 \%$ & & & \\
\hline & & & & \\
\hline
\end{tabular}

$\left({ }^{*}=\right.$ significant $)$

Based on the analysis of variance as shown in Table 4 , it is obtained that $\mathrm{R}^{2}$ is $80.53 \%$, which means that the storage time of the cocoa fruit, aeration rate and temperature of the fermenter have an effect of $80.53 \%$ on the color of dry cocoa beans, while the remaining $-80.53 \%=19.47 \%$ is influenced by other variables outside of this model. This shows that there are other factors that affect the color of the hue in dried seed pieces, as occurs in chroma. Furthermore, when viewed from the P-value of the models and variables observed, it is known that only a part of the model and variables have a significant effects on the model, as shown in Table 3. The mathematical model obtained to predict the color of dried cocoa beans based on analysis using RSM is:

$$
\begin{array}{r}
Y=-100.959+3.357 X_{1}-47.814 X_{2}+5.525 X_{3}+ \\
0.193 X_{1}^{2}-122.364 X_{2}^{2}-0.054 X_{3}^{2}+0.113 X_{1} X_{2} \\
-0.092 X_{1} X_{3}+2.305 X_{2} X_{3} \ldots \ldots \ldots \ldots \ldots \ldots \ldots \ldots \ldots \ldots \ldots \ldots \ldots \ldots \ldots \ldots
\end{array}
$$



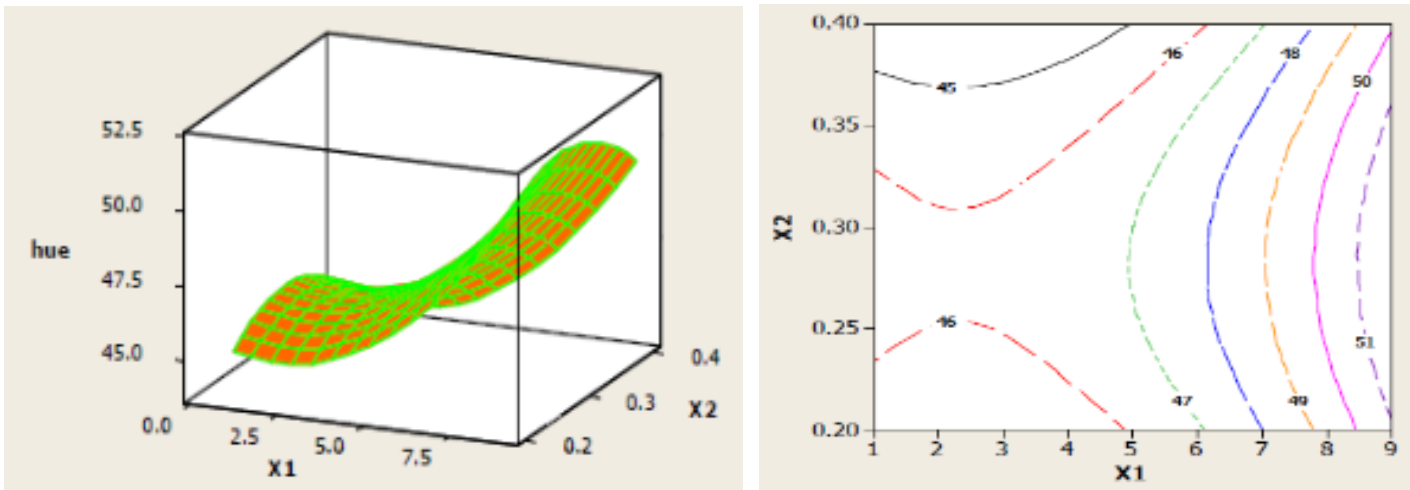

Figure 6. Plot surface and contour relationship between the hue color of fermented cocoa beans and the storage time of cocoa fruit $\left(X_{1}\right)$ and aeration rate $\left(X_{2}\right)$ at the fermenter air temperature $\left(X_{3}\right)=50{ }^{\circ} \mathrm{C}$
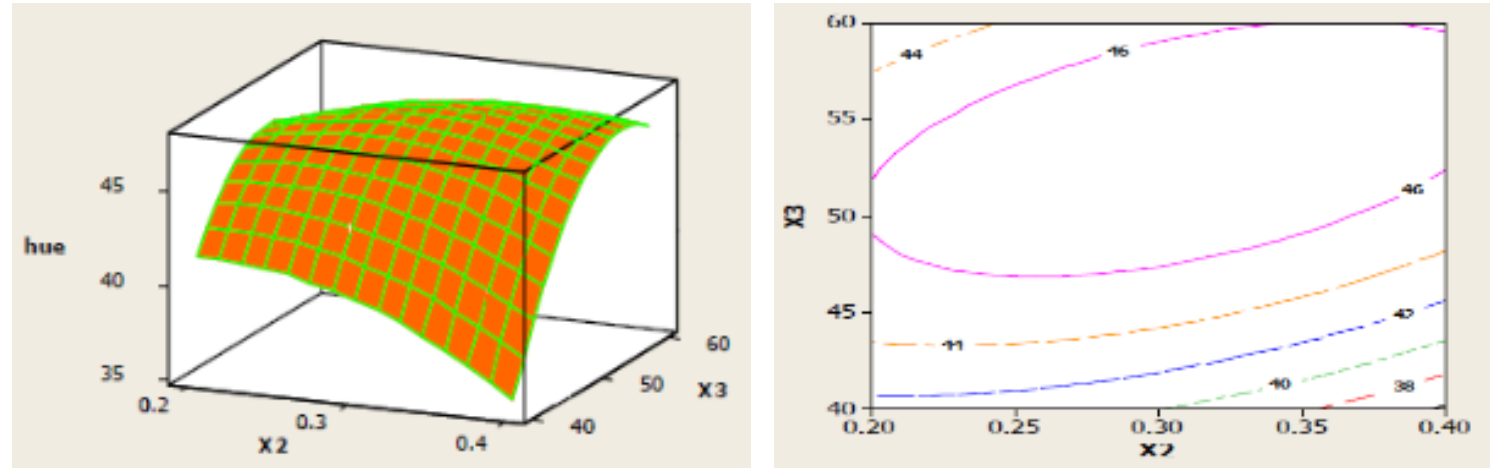

Figure 7. Plot surface and contour relationship between the hue of fermented dried cocoa beans to an aeration rate $\left(X_{2}\right)$ and the temperature of the fermenter air $\left(X_{3}\right)$ at the time of cacao fruit ripening $\left(X_{1}\right)=5$ days
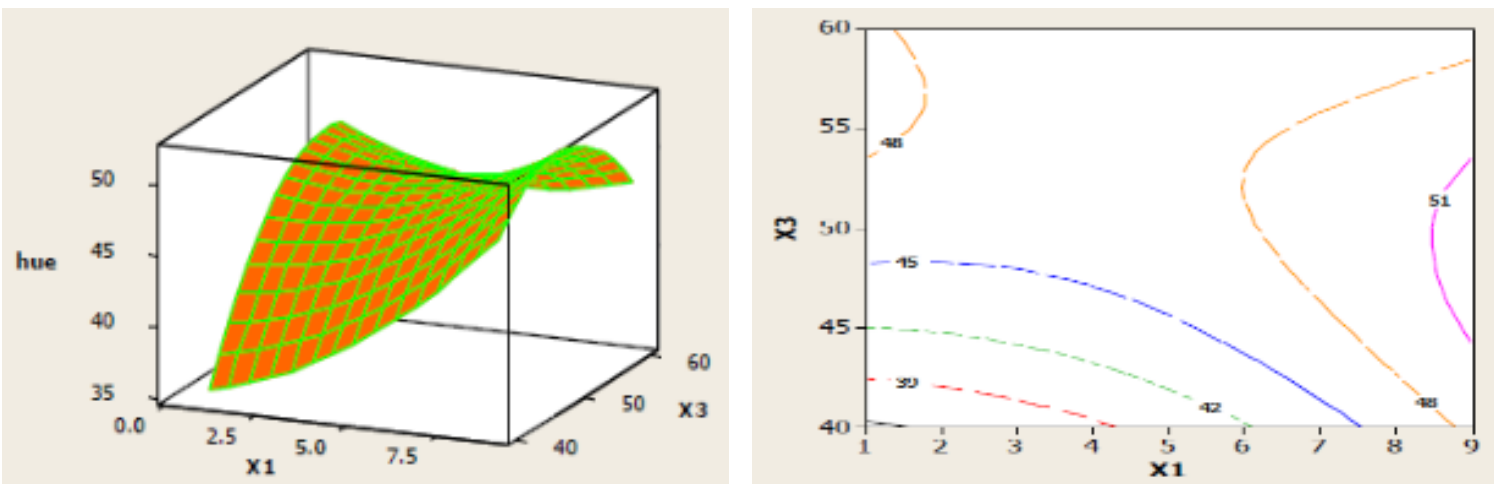

Figure 8. Plot surface and contour of the relationship between the hue color of the fermented cocoa beans and the curing time of cocoa fruit $\left(X_{1}\right)$ and the fermenter air temperature $\left(X_{3}\right)$ at the aeration rate $\left(X_{2}\right)=0.3$ liters/minute

Based on Figure 6, it is known that when the time of 2 days, aeration rate of 0.4 liters/minute, fermenter air temperature is set to $50{ }^{\circ} \mathrm{C}$, with and fermenter air temperature of $50{ }^{\circ} \mathrm{C}$. Figure 7 fruit storage time of 9 days and an aeration rate of shows that when the cacao fruit storage time is set 0.2-0.4 liters/minute, the color range of hue is 45 for 5 days, the color hue prediction is 37-47, with - 51. The highest hue color is \pm 51 obtained at the an aeration rate of $0.2-0.4$ liters/minute and a fermenter air temperature of $50^{\circ} \mathrm{C}$, aeration rate fermenter air temperature of $40-60^{\circ} \mathrm{C}$. The highest of $0.2-0.35$ liters/minute, and the storage time of color hue is 47.4 obtained at the storage time of 9 days. The lowest color of hue is 44 , with a storage 5 -day, aeration rate of 0.3 liters/minute, and the 

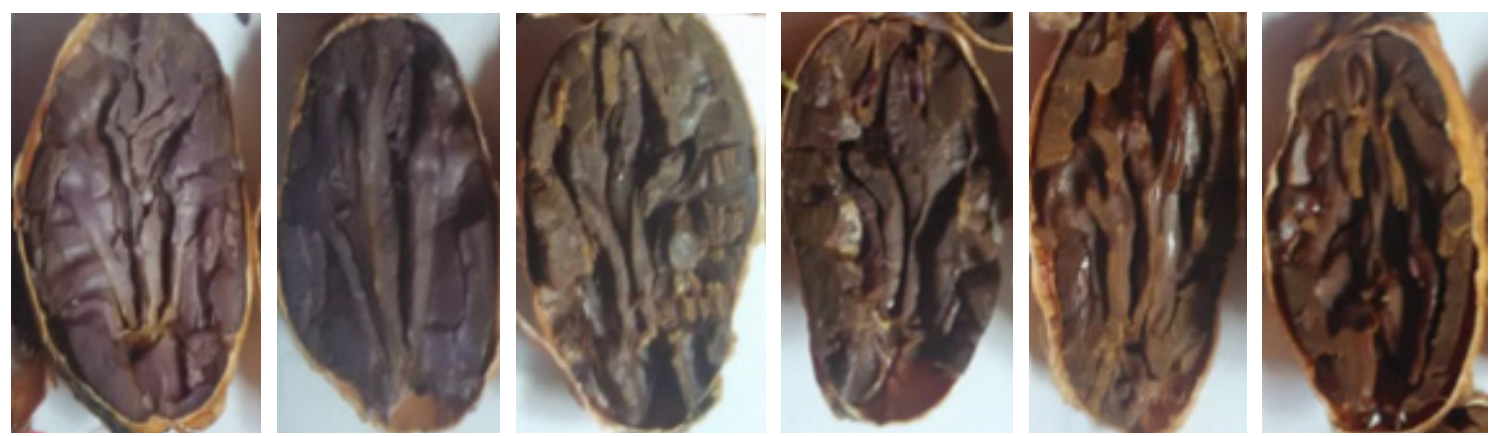

Figure 9. Color samples of dried cocoa beans in several fermentation treatments

fermenter air temperature of $54{ }^{\circ} \mathrm{C}$. The lowest color of the hue is \pm 36 obtained at the storage time of 5 days, aeration rate of 0.4 liters/minute, and fermenter air temperature of $40{ }^{\circ} \mathrm{C}$.

Figure 8 shows that when the aeration rate is set to 0.3 liters/minute, the highest color prediction of hue is $50-51$ at the fermenter air temperature of $45-53{ }^{\circ} \mathrm{C}$ and the storage time of 9 days. Meanwhile, the lowest hue color is 35.8 obtained at an aeration rate of 0.3 liters/minute, 1 -day cocoa fruit storage time and a fermenter air temperature of 40 ${ }^{\circ} \mathrm{C}$. Based on the illustration in Figure 6, Figure 7 and Figure 8, it is known that the prediction of the highest hue color value is 51.8 obtained at the storage time of 9 days, aeration rate of 0.3 liters/ minute, and a fermenter air temperature of $50^{\circ} \mathrm{C}$. Meanwhile, the lowest color of hue is 35.8 obtained at the storage time of 1 day, aeration rate of 0.3 liters/minute, and fermenter air temperature of $40{ }^{\circ} \mathrm{C}$, or at the storage time of 5 days, an aeration rate of 0.4 liters/minute, and fermenter air temperature of $40^{\circ} \mathrm{C}$.

\section{Visual RGB color analysis}

RGB color analysis on fermented and nonfermented pieces of dried cocoa beans was carried out using the help of color analysis (RESEARCH LAB TOOLS) software as shown in Figure 2, starting with inputting the $L^{*}, a^{*}, b^{*}$ measurements into software and doing calculate command to get the result. The calculation results for the color analysis (RESEARCH LAB TOOLS) displayed are $L^{*}$, chroma, hue, and color visualization and RGB color acquisition as shown in Table 1 and 2. Based on the RGB color visualization of dried cocoa beans, it is known that the color range of $\mathrm{R}$ or the red color of cocoa beans after fermentation was higher when compared to unfermented cocoa beans. Furthermore, the range of $\mathrm{G}$ (green) or green colors also had the same tendency, which was the color of $G$ in the fermented cocoa beans was slightly higher than the unfermented sample. On the contrary, the color values of B (blue) or blue had a different tendency, that was fermented dried cocoa beans had a lower blue range than unfermented cocoa beans.

The RGB color visualization of the dried cocoa beans shown in Table 1 and Table 2 is a visual depiction of the average color values of the fermented dried cocoa beans samples that have been made. Meanwhile, the color of some samples of fermented dried cocoa beans are shown in Figure 9. Based on Figure 9, it is known that each treatment has different influence on the color and characteristics of the pieces of cocoa beans. The treatments of cacao fruit storage time, aeration rate, and fermenter air temperature are known to have an influence on the RGB color visualization produced. In addition, as stated earlier that the fermentation of cocoa beans carried out using this system still has disadvantages in terms of air aeration because the distribution of aeration given has not been able to 
reach all the cocoa beans in the reactor tube. So that the uniformity of the color of the pieces of cocoa beans in each treatment produced has not been achieved well.

Storage time of the cacao fruits also has a little effect on the difference in the color values of the unfermented dried cocoa beans produced. It is known that storing the cocoa fruits will change the color combination of dried cocoa beans, where the longer storage or ripening of the cocoa fruit will reduce the slaty seeds, which is accompanied by the appearance of brown color on the dried cocoa beans produced. According to Sulaiman and Yang (2015), fresh cocoa beans which are dried directly without fermentation will produce $93 \%$ of slaty seeds and $7 \%$ of fully purple seeds. However, the color characteristics of cocoa beans are not the only indicator used to measure the quality of cocoa beans. According to Afoakwa et al. (2012), there are several indicators of the quality of fermented cocoa beans including having good brown color, low bitter and slaty taste, and the absence of excessive taste or smell of smoke and acid.

\section{CONCLUSION}

The treatment of cacao fruit storage time before fermentation, aeration rate, and fermenter air temperature have an influence on the color values of $\mathrm{L}^{*}, \mathrm{a}^{*}, \mathrm{~b}^{*}$, chroma, hue, and RGB of dried cocoa beans produced. Prediction value based on data analysis using response surface methodology shows that the highest brightness level of chroma color is \pm 26 obtained at the storage time of ripening of 9-day cocoa fruit, aeration rate of 0.4 liters/ minute, and the fermenter air temperature of 50 ${ }^{\circ} \mathrm{C}$. Meanwhile, the prediction of the highest hue color value is 51.8 obtained at storage time of 9 days, aeration rate of 0.3 liters/minute, and the fermenter air temperature of $50^{\circ} \mathrm{C}$. Furthermore, the RGB color of dried cocoa beans shows that the color range of R (red) and G (green) of cocoa beans after fermentation is higher when compared to cocoa beans without fermentation, while the value of color B (blue) has a different tendency, which is dried fermented cocoa beans have a lower blue range compared to unfermented cocoa beans.

\section{REFERENCES}

Afoakwa, E. 0. 2016. Chocolate Science and Technology. second Edi. United Kingdom: Wiley Blackwell.

Afoakwa E. O., Q. Jennifer, S. B. Agnes, S. T. Jemmy, and K. S. Firibu. 2012. "Influence of Pulp-Preconditioning and Fermentation on Fermentative Quality and Appearance of Ghanaian Cocoa (Theobroma Cacao) Beans." International Food Research Journal 19(1):127-33.

Afoakwa, Emmanuel Ohene, Jennifer Quao, Jemmy Takrama, and Agnes Simpson Budu. 2011. "Chemical Composition and Physical Quality Characteristics of Ghanaian Cocoa Beans as Affected by Pulp Pre-Conditioning and Fermentation." (ICCO 2009).

Bitaraf, Mona Sadat, Faramarz Khodaiyan, Mohammad Amin Mohammadifar, and Seyed Mohammad Mousavi. 2012. "Application of Response Surface Methodology to Improve Fermentation Time and Rheological Properties of Probiotic Yogurt Containing Lactobacillus Reuteri." Food and Bioprocess Technology 5(4):1394-1401.

Dinar, Latifa, Atris Suyantohadi, and M. Affan Fajar Falah. 2012. "Pendugaan Kelas Mutu Berdasarkan Analisa Warna Dan Bentuk Biji Pala ( Myristica Fragrans Houtt ) Menggunakan Teknologi Pengolahan Citra Dan Jaringan Saraf Tiruan." Jtep 26(1):53-59.

Hartuti, Sri and Muhammad Dani Supardan. 2013. "Optimasi Ekstraksi Gelombang Ultrasonik Untuk Produksi Oleoresin Jahe (Zingiber Officinale Roscoe) Menggunakan Response Surface Methodology (RSM)." Agritech 33(4):415-23.

Indarto1,Murinto2. 2017. “Deteksi Kematangan Buah Pisang Berdasarkan Fitur Warna Citra Kulit Pisang Menggunakan Metode Transformasi Ruang Warna HIS." JUITA P-ISSN: 2086-9398; Volume V,(May).

Khuri, Andre I. 2017. "Response Surface Methodology and Its Applications In Agricultural and Food Sciences." Biometrics \& Biostatistics International Journal 5(5).

Kongor, John Edem, Michael Hinneh, Davy Van de Walle, Emmanuel Ohene Afoakwa, Pascal Boeckx, and Koen Dewettinck. 2016. "Factors Influencing Quality Variation in Cocoa (Theobroma Cacao) Bean Flavour Profile - A Review." Food Research International 82:44-52.

Krähmer, Andrea, Annika Engel, Daniel Kadow, Naailah Ali, Pathmanathan Umaharan, Lothar W. Kroh, and Hartwig Schulz. 2015. "Fast and Neat - Determination of Biochemical Quality Parameters in Cocoa Using near Infrared Spectroscopy." Food Chemistry 181:152-59.

Marcin, Kurek, Wyrwisz Jarosław, Piwiska Monika, and Wierzbicka Agnieszka. 2016. "Application of the Response Surface Methodology in Optimizing Oat Fiber Particle Size and Flour Replace- 
ment in Wheat Bread Rolls." CYTA - Journal of Food 14(1):18-26.

Mardhotillah, Atika, Anditya Atfianto, and Kurniawan Nur Rahmadhani. 2018. "Menghitung Jumlah Buah Cabe Berwarna Hijau Menggunakan Metode Transformasi Ruang Warna RGB." 5(2):3641-48.

Mendoza, Fernando, Petr Dejmek, and José M. Aguilera. 2007. “Colour and Image Texture Analysis in Classification of Commercial Potato Chips." Food Research International 40(9):1146-54.

Menezes, Aline Galvão Tavares, Nadia Nara Batista, Cintia Lacerda Ramos, Adriana Reis de Andrade e Silva, Priscila Efraim, Ana Carla Marques Pinheiro, and Rosane Freitas Schwan. 2016. "Investigation of Chocolate Produced from Four Different Brazilian Varieties of Cocoa (Theobroma Cacao L.) Inoculated with Saccharomyces Cerevisiae." Food Research International 81:83-90.

Munarso, S. Joni. 2016. "Postharvest Handling to Increase Cocoa Bean Quality and Its Competitiveness."

Perkebunan, Puslitbang. 2010. Budidaya Dan Pascapanen Kakao. Indonesia: Pusat Penelitian dan Pengembangan Perkebunan.

Sulaiman, Khairul Bariah and Tajul Aris Yang. 2015. "Color Characteristics of Dried Cocoa Using Shallow Box Fermentation Technique." 9(12):1256-60.

Wexler, Lea, Ana M. Perez, Elba Cubero-Castillo, and Fabrice Vaillant. 2016. "Use of Response Surface Methodology to Compare Vacuum and Atmospheric Deep-Fat Frying of Papaya Chips Impregnated with Blackberry Juice." CyTA - Journal of Food 6337(September):1-9. 